\title{
The use of solar radiation for generating heat in a solar air collector in northern Poland
}

\author{
Jolanta Fieducik ${ }^{1, *}$ \\ ${ }^{1}$ University of Warmia and Mazury in Olsztyn, Faculty of Technical Sciences, 10-900 Olsztyn, \\ Poland
}

\begin{abstract}
This article analyzes the use of solar radiation for generating heat in a simple solar air collector built in a laboratory. The structure of the collector and the equipment for measuring physical parameters were described. The aim of the study was to analyze the operating parameters and the thermal efficiency of a solar air collector in northern Poland. Various applications of solar air collectors were discussed. Solar air collectors can be used for heating, ventilating and drying indoor premises and for heating water.
\end{abstract}

\section{Introduction}

Global fossil fuel depletion has increased the interest in solar energy for generating electricity and heat $[1,2]$. This is a particularly important consideration in small buildings whose energy needs can be fully met by solar energy. Single-family homes meet the above definition. Cheap in the construction and operation of air collectors can be used for heating, drying, ventilation and hot water heating. New solutions in the construction of air collectors are introduced based on new research. Numerical analyzes [13] and modeling using the Green function [14] are carried out for research in the field of flow, heat transfer and flat plate constructions. Collectors are tested with heat absorbing plates [15], or with an absorber consisting of containers filled with phase change material [16]. The purpose of these tests is to ensure the highest possible heat transfer efficiency and minimize the costs of building air collectors. In the new type of solar collector with a parabolic concentrator (CPC) (SAC) and a flat microthermal tube system (FMHPA), an average efficiency of $61 \%$ was achieved, and the instantaneous efficiency was $68 \%$ [18]. The aim of this study was to analyze the applicability of solar air collectors for generating heat in northern Poland. In Poland the average annual irradiation on a horizontal plane is in the range $950-1150 \mathrm{kWh} / \mathrm{m}^{2}$. In Olsztyn, this irradiation is around $950-1000 \mathrm{kWh} / \mathrm{m}^{2}$. The analysis was performed in the city of Olsztyn with the use of a simple solar air collector built in a laboratory.

\footnotetext{
*Corresponding author: jolanta.fieducik@uwm.edu.pl
} 


\section{Conversion of solar radiation}

The Sun is the main source of energy reaching the Earth. The electromagnetic radiation emitted by the Sun has a broad wavelength spectrum of around $0.2-2.5 \mu \mathrm{m}$, and the transmitted energy varies subject to wavelength. The radiation emitted by an ideal blackbody at a given frequency of the electromagnetic wave is described by Planck's law and can be expressed by the following formula [4]:

where:

$$
I(f)=\frac{2 h f^{3}}{c^{3}} \cdot 1 /\left(e \frac{h f}{k T}-1\right)
$$

$I(\mathrm{f})$ - spectral radiance (radiance of a surface per unit frequency)

$h$ - Planck constant of $6.626 \cdot 10^{-34} \mathrm{Js}$

$T$ - absolute temperature (K) of a blackbody

$c$ - speed of light (in vacuum)

$k$-Boltzmann constant

$f$-radiation frequency (for which irradiance is calculated)

The dependency between solar irradiance and wavelength is presented in Figure 1.

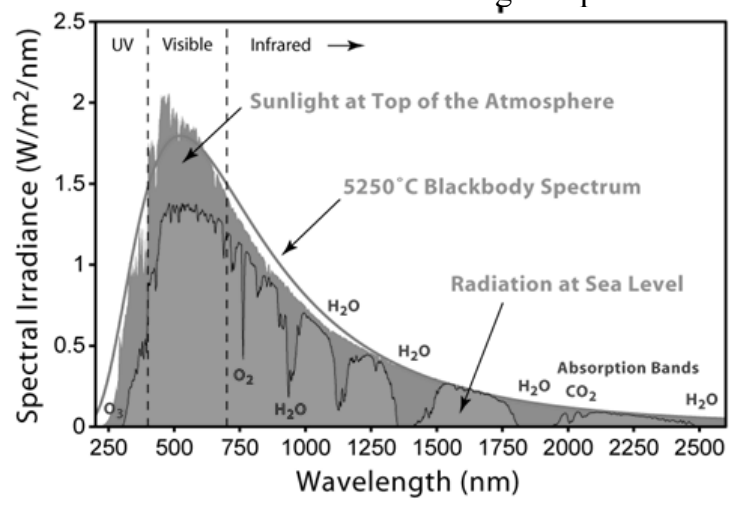

Fig. 1. Distribution of solar irradiance subject to wavelength [5].

Solar spectral irradiance reaching the upper layer of the Earth's atmosphere and the radiation reaching the surface of the Earth are presented in Figure 1. Solar irradiance in the visible range occupies the wavelength of 350 to $750 \mathrm{~nm}$. Solar energy that reaches the ground is around $46 \%$ visible light, $7 \%$ ultraviolet light and $47 \%$ infrared light.

Total solar irradiance can be determined with the use of the Stefan-Boltzmann law which defines the total electromagnetic energy radiated per unit surface area of an ideal blackbody at a given temperature.

The Stefan-Boltzmann law is expressed by the below formula [6]:

$$
\Phi=\sigma T^{4}
$$

where:

$\Phi-$ energy radiated per unit area of a body $\left[\mathrm{W} / \mathrm{m}^{2}\right]$

$\sigma$-Stefan-Boltzmann constant

$T$ - temperature $(\mathrm{K})$

The overall energy carried by solar radiation to the upper layer of the Earth's atmosphere is estimated at $1.39 \mathrm{~kW} / \mathrm{m}^{2}$, and it is referred to as the solar constant. Solar radiation is reflected, absorbed and diffused in the atmosphere, and only $1 \mathrm{~kW} / \mathrm{m}^{2}$ of that energy reaches 
the surface of the Earth on a cloudless day. The loss of solar radiation in the atmosphere is presented in Figure 2.

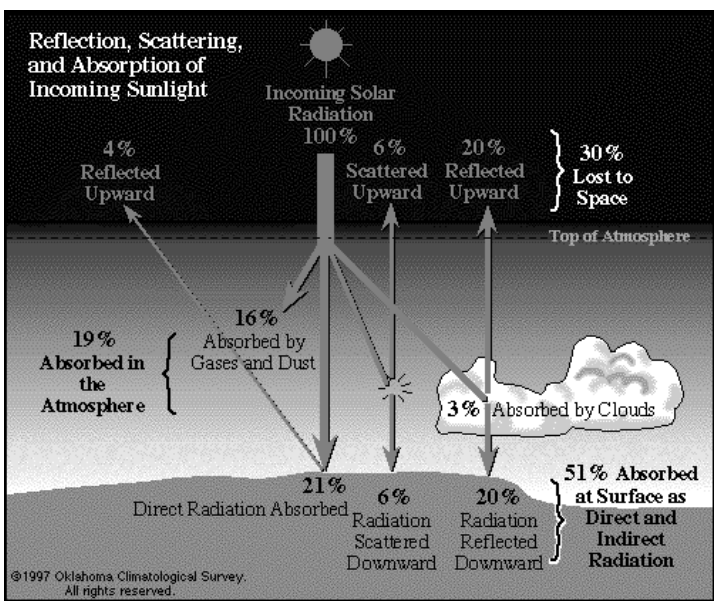

Fig. 2. Distribution of solar radiation reaching the surface of the Earth [8].

Solar irradiance on the surface of the Earth is also determined by the Sun's position relative to the zenith and the thickness of the atmospheric layer which absorbs solar radiation. The loss of solar radiation in the atmosphere resulting from differences in the solar zenith angle is defined by the air mass (AM) coefficient. In Figure 3, coefficient AM is defined by the quotient of the optical path length $\mathrm{L}$ of solar radiation passing the Earth's atmosphere and path length $\mathrm{L}_{0}$ at the zenith. Coefficient $A M$ can be used to describe the solar spectrum after sunlight has crossed the atmosphere, and it is widely applied to calculate the efficiency of solar cells under normalized conditions. Air mass is expressed by appending its value to the acronym AM, for example AM1.5 [9].

$$
A M=L / L_{0}=1 / \cos (\Theta z)
$$

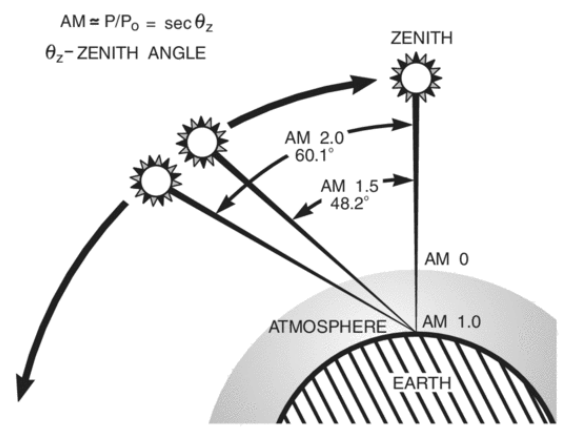

Fig. 3. Dependency between coefficient AM (Air Mass) and the zenith angle [9].

Solar irradiance is also significantly influenced by weather conditions in a given location and time. Solar irradiance can reach $1000 \mathrm{~W} / \mathrm{m}^{2}$ on a cloudless day, and it decreases to around $50 \mathrm{~W} / \mathrm{m}^{2}$ on a cloudy winter day. Solar irradiance is determined by season and sunshine duration which is estimated at $3500 \mathrm{~h} /$ year in locations with high solar exposure. In Poland, 
sunshine duration ranges from 1300 to $1900 \mathrm{~h} /$ year, and it is estimated at $1550 \mathrm{~h} /$ year in north-eastern Poland on average.

\section{Solar air collectors - structure and operation}

Several types of solar air collectors are in use. They differ in structure, but operate on a similar principle. A solar air collector consists of an absorber plate, a transparent cover plate and, in some cases, a heat insulating layer. The absorber plate is the most important part of a collector. Solar energy is transferred to the absorber which heats the flowing air stream. Solar air collectors have numerous advantages. The absorbing medium is air which does not freeze, heats up rapidly and can be directly used to heat indoor premises.

Solar air collectors can be uncovered or covered. In uncovered collectors, sunlight falls directly on the absorber plate, whereas in covered collectors, the absorber plate is mounted under a transparent cover plate. Depending on the solution, the air stream flows above or under the absorber, and in more complex structures - above and under the absorber or through the absorber. In the most advanced collectors, air flows through specially profiled channels. Collector channels have rectangular, triangular or oval cross-section. The absorber plate can be flat, rough or porous to increase the absorbing area and maximize the efficiency of heat transfer between the absorber and the air stream. In collectors with perforated absorbers, air is sucked in by the openings, which maximizes contact between the air stream and the absorber and increases the efficiency of heat transfer.

The operating principle of a solar air collector is presented in a schematic diagram in Figure 4.

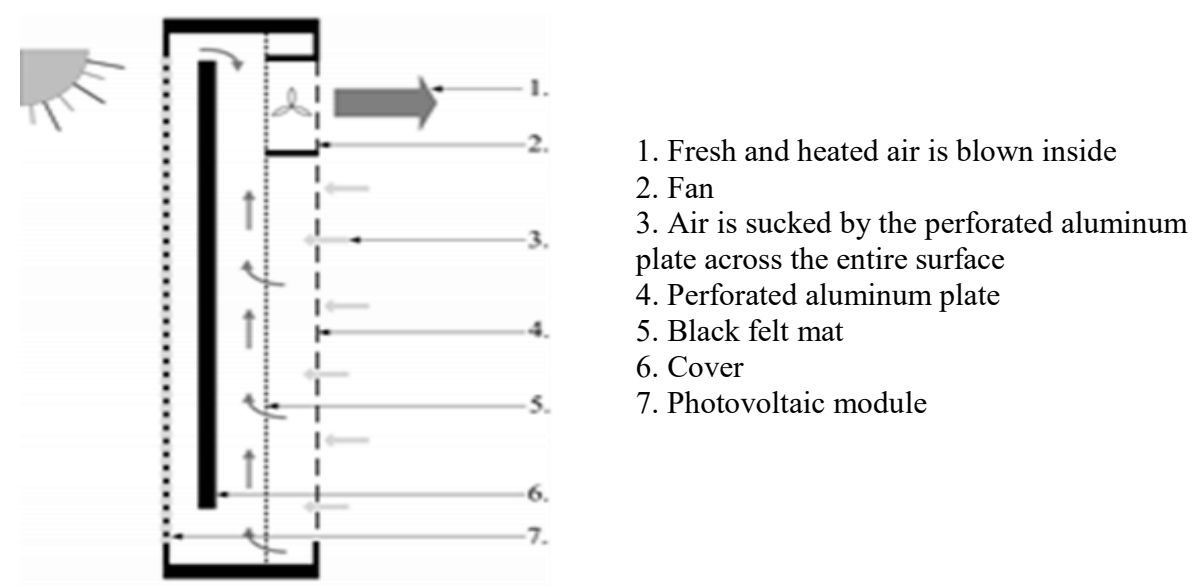

Fig. 4. The operating principle of a solar air collector $[10,11]$.

In solar air collectors, air is the heat absorbing medium, and solar energy is efficiently converted to heat [1-3]. In the temperature range characteristic of the Earth's climate, air is not susceptible to phase change; therefore, changes in temperature do not disrupt the operation of a solar air collector. Air heated inside the collector can be directly used to heat indoor premises without the involvement of additional media.

A solar air collector can also be used for indoor ventilation. Air flow and air temperature are easily controlled, and the thermodynamic status of the premises connected to a solar air collector can be easily monitored. 


\section{Parameters of the analyzed solar air collector}

Below is presented geographical location and climatic data of Olsztyn. Olsztyn lies on the northern latitude: 53.78 and east longitude: 20.48 . The height of the position from 87.7 to $154.4 \mathrm{~m}$. The climate in Olsztyn is moderately cold, with an average temperature of $7.9^{\circ} \mathrm{C}$. In Olsztyn the average annual rainfall is $635 \mathrm{~mm}$. The solar radiation is $900-950 \mathrm{kWh} / \mathrm{m}^{2}$. The average exposure to the Sun is about 1,600 hours a year. The average wind speed during the year reaches the level of $3.0 \mathrm{~m} / \mathrm{s}$. The analyzed solar air collector was built in a laboratory. Collector dimensions were $2700 \times 1400 \times 150 \mathrm{~mm}$, the dimensions of the aluminum sheet absorber were $2500 \times 1250 \mathrm{~mm}$, and total absorption area was $3.125 \mathrm{~m}^{2}$. The absorber plate was covered with matte black paint on both sides. The absorber was mounted inside a wooden box whose rear and side walls were insulated with a layer of felt on the inside and styrofoam on the outside. The collector was covered with a 4-cm-thick glass pane. The aluminum absorber plate was mounted at a distance of $25 \mathrm{~mm}$ from the rear wall and $30 \mathrm{~mm}$ from the glass cover to enable free air flow and heat collection on both sides of the absorber. Two 9G180 NMB fans (12 V, 1.34 A) supplied by a $25 \mathrm{~W}$ photovoltaic module (12 V) were used for forced air circulation inside the collector.

The solar air collector was used to heat a residential building. The cold air inlet and the heated air outlet were positioned on the same side of the collector based on the building's layout and the assumption that cold air drawn from the building would be heated and returned to the building. A schematic diagram of the collector and airflow are presented in Figure 5.

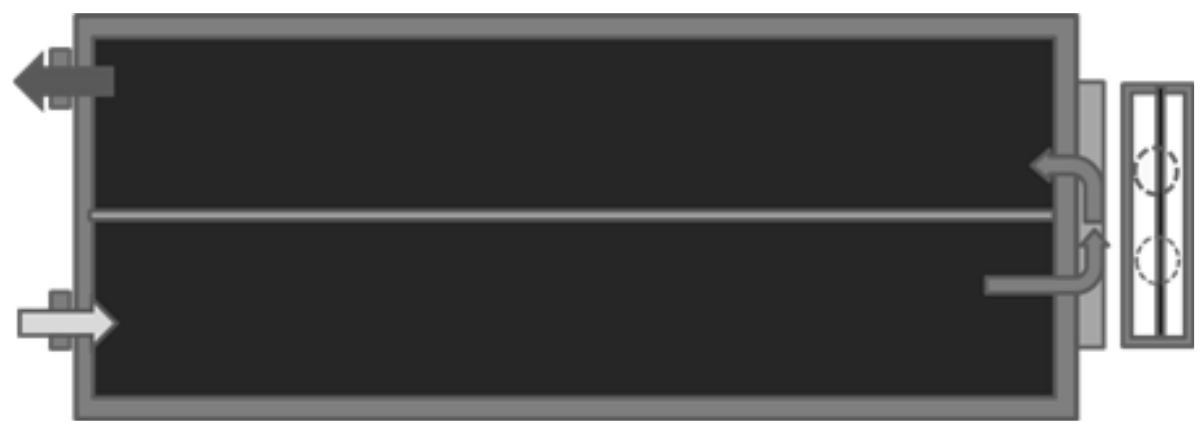

Fig. 5. Schematic diagram of the collector and airflow inside the collector.

The collector was positioned around $5 \mathrm{~m}$ above ground level at $205^{\circ}$ to the south $\left(25^{\circ}\right.$ to the west). The angle of inclination between the collector and the ground was $45^{\circ}$ to capture more sunlight in autumn and winter. Solar irradiance was measured with the 6450 DAVIS solar radiation sensor which measures both direct and diffuse components of solar irradiance. Air temperature at the collector inlet was measured with the VA18B multimeter with a temperature converter, and the signal was supplied to the RS232 terminal and registered by a computer. Air flow rate, temperature and humidity at the collector outlet were measured with the MS6252B MASTECH digital anemometer.

\section{Results and discussion}

The research was carried out from February 2015 to March 2016. The data collected during the period 27- 30 September 2015 selected for the analysis of the collector efficiency were presented in Fig. 6. Solar irradiance, air temperature at the collector outlet and the energy flux measured between 27 and 30 September 2015 are presented graphically in Figure 7. 
Cool air flowing through the collector is heated by solar radiation, and its temperature and enthalpy increase. The process of heating air with humidity $\mathrm{X}$ from temperature $T_{1}$ to $T_{2}$ inside the collector is associated with changes in enthalpy $\Delta h$ and an increase in internal energy $\Delta e$ :

$$
\Delta h=\Delta e=h_{2}(1+X)-h_{1}(1+X)=1.006 \cdot\left(T_{2}-T_{1}\right)+1.86 \cdot X \cdot\left(T_{2}-T_{1}\right)
$$

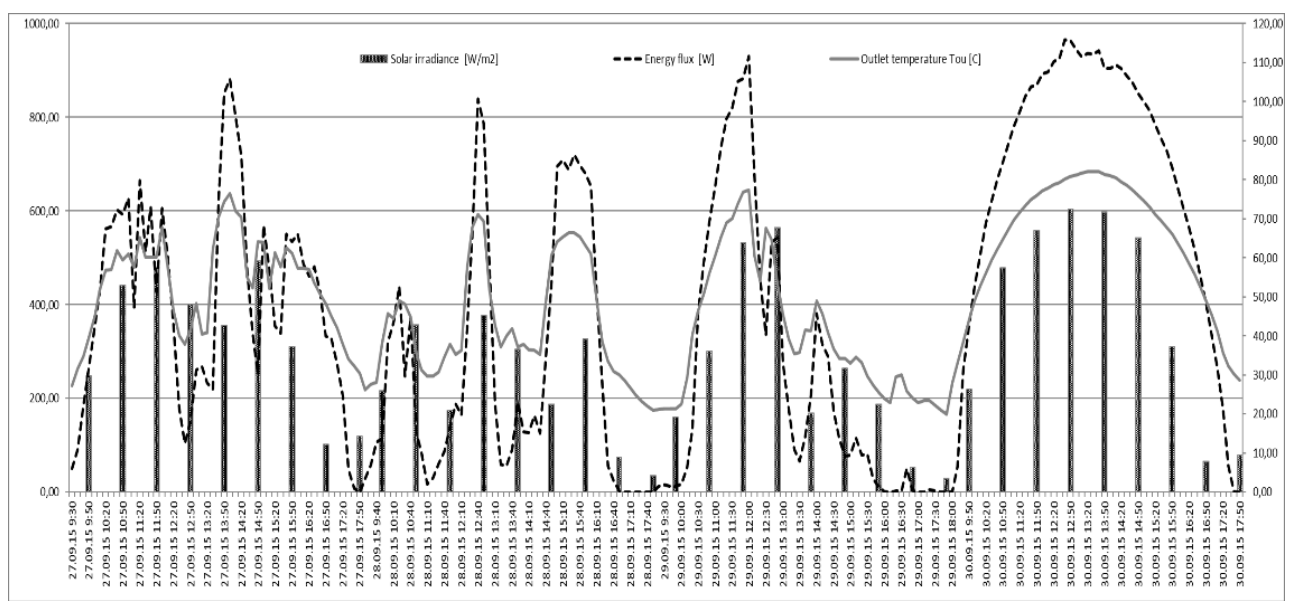

Fig. 6. Data registered on 27-30 September 2015.

The mass flux $m$ of air with density $\rho$ is calculated based on the velocity $v$ of air leaving the collector with cross-section $S_{\mathrm{w}}$ :

$$
m=\rho \cdot v \cdot S_{\mathrm{w}}
$$

The energy flux $e[\mathrm{~W}]$ transferred by heated air in the collector is:

$$
e=m \cdot \Delta h
$$

The collector's thermal efficiency $\eta$ can be determined based on energy flux $e$, the collector's surface area $S_{\mathrm{k}}$ and solar irradiance $I$ :

$$
\eta=e / I \cdot S_{k}
$$

The collector's thermal efficiency was calculated based on the data registered on 30 September 2015, a relatively cloudless day, to minimize the effects of external factors. 


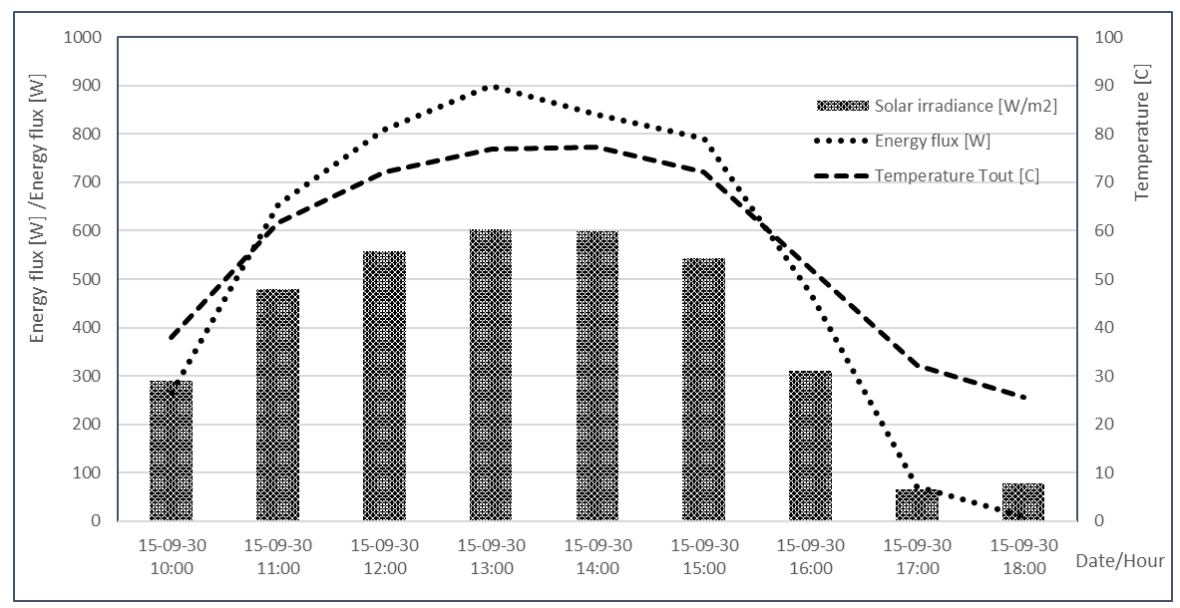

Fig. 7. Data registered on 30 September 2015.

The data for calculating the collector's thermal efficiency are presented graphically in Figure 7 , and the results are presented in Table 1.

Table 1. Collector's thermal efficiency based on the data registered on 30 September 2015.

\begin{tabular}{|c|c|c|c|c|c|c|c|c|c|}
\hline Date/hour & $\begin{array}{c}\text { Temper } \\
\text { ature } \\
\text { Tout }[\mathrm{C}]\end{array}$ & $\begin{array}{c}\text { Humi } \\
\text { dity } \\
{[\%]}\end{array}$ & $\begin{array}{c}\text { Air } \\
\text { veloc } \\
\text { ity } \\
{[\mathrm{m} / \mathrm{s}]}\end{array}$ & $\begin{array}{l}\text { ho } \\
{[\mathbf{k J} /} \\
\text { kg] }\end{array}$ & $\begin{array}{c}\text { h } \\
{[\mathbf{k J} /} \\
\mathbf{k g}]\end{array}$ & $\begin{array}{c}\Delta \mathbf{h} \\
{[\mathrm{kJ} /} \\
\mathbf{k g}]\end{array}$ & $\begin{array}{c}\text { Ener } \\
\text { gy } \\
\text { flux } \\
{[W]}\end{array}$ & $\begin{array}{c}\text { Solar } \\
\text { irradia } \\
\text { nce } \\
{\left[\mathbf{W} / \mathbf{m}^{2}\right.} \\
]\end{array}$ & $\begin{array}{c}\text { Efficie } \\
\text { ncy } \\
{[\%]}\end{array}$ \\
\hline $\begin{array}{c}15-09-30 \\
10: 00 \\
\end{array}$ & 38.02 & $31.1 \%$ & 3.91 & $\begin{array}{c}62.0 \\
5 \\
\end{array}$ & $\begin{array}{c}80.3 \\
9\end{array}$ & $\begin{array}{c}18.3 \\
5\end{array}$ & $\begin{array}{c}264 . \\
96\end{array}$ & 291 & $38.7 \%$ \\
\hline $\begin{array}{c}15-09-30 \\
11: 00\end{array}$ & 61056 & $9.3 \%$ & 4.19 & $\begin{array}{c}62.4 \\
9\end{array}$ & $\begin{array}{c}104 . \\
69\end{array}$ & $\begin{array}{c}42.4 \\
0\end{array}$ & $\begin{array}{c}653 . \\
89\end{array}$ & 479 & $43.7 \%$ \\
\hline $\begin{array}{c}15-09-30 \\
12: 00 \\
\end{array}$ & 72.10 & $4.6 \%$ & 4.14 & $\begin{array}{c}62.7 \\
2 \\
\end{array}$ & $\begin{array}{c}115 . \\
58\end{array}$ & $\begin{array}{c}52.8 \\
6 \\
\end{array}$ & $\begin{array}{c}809 . \\
27\end{array}$ & 558 & $46.4 \%$ \\
\hline $\begin{array}{c}15-09-30 \\
13: 00\end{array}$ & 76.79 & $2.4 \%$ & 4.18 & $\begin{array}{c}62.2 \\
7\end{array}$ & $\begin{array}{c}120 . \\
41\end{array}$ & $\begin{array}{c}58.1 \\
5\end{array}$ & $\begin{array}{c}898 . \\
91\end{array}$ & 603 & $47.7 \%$ \\
\hline $\begin{array}{c}15-09-30 \\
14: 00\end{array}$ & 77.35 & $1.4 \%$ & 4.17 & $\begin{array}{c}66.6 \\
5\end{array}$ & $\begin{array}{c}120 . \\
98\end{array}$ & $\begin{array}{c}54.3 \\
4\end{array}$ & $\begin{array}{c}838 . \\
69\end{array}$ & 598 & $44.9 \%$ \\
\hline $\begin{array}{c}15-09-30 \\
15: 00 \\
\end{array}$ & 72.21 & $1.4 \%$ & 4.17 & $\begin{array}{c}64.5 \\
1 \\
\end{array}$ & $\begin{array}{c}115 . \\
69 \\
\end{array}$ & $\begin{array}{c}51.1 \\
8 \\
\end{array}$ & $\begin{array}{c}789 . \\
47 \\
\end{array}$ & 543 & $46.5 \%$ \\
\hline $\begin{array}{c}15-09-30 \\
16: 00\end{array}$ & 52.10 & $2.7 \%$ & 4.18 & $\begin{array}{c}64.5 \\
5\end{array}$ & $\begin{array}{c}94.9 \\
3\end{array}$ & $\begin{array}{c}30.3 \\
8\end{array}$ & $\begin{array}{c}469 . \\
15\end{array}$ & 310 & $48.4 \%$ \\
\hline $\begin{array}{c}15-09-30 \\
17: 00\end{array}$ & 32.12 & $6.0 \%$ & 1.94 & $\begin{array}{c}64.1 \\
6\end{array}$ & $\begin{array}{c}74.3 \\
0\end{array}$ & $\begin{array}{c}10.1 \\
5\end{array}$ & $\begin{array}{c}72.7 \\
7\end{array}$ & 65 & $35.8 \%$ \\
\hline $\begin{array}{c}15-09-30 \\
18: 00\end{array}$ & 25.65 & $10.3 \%$ & 0.80 & $\begin{array}{c}64.0 \\
8\end{array}$ & $\begin{array}{c}67.6 \\
2\end{array}$ & 3.55 & $\begin{array}{c}10.4 \\
9\end{array}$ & 78 & $4.3 \%$ \\
\hline
\end{tabular}

Based on the data registered on 30 September 2015, the collector's maximum thermal efficiency was determined at $48.4 \%$, and average efficiency was estimated at $40 \%$.

\section{Conclusions}


One of the greatest advantages of solar air collectors is that they rely on air as a working medium that never freezes. Solar air collectors can be used for indoor heating, ventilation, drying and water heating [12]. The amount of heat supplied by a collector is determined by solar irradiance in a given time and location. Therefore, to introduce solar energy technologies it is necessary to promote them as modern options for energy conservation in buildings that should be implemented when energy-efficient measures have already been applied. Thus both options can reduce total energy consumption significantly and, in consequence, reduce environmental pollution [17]. Solar air collectors can also be deployed as backup heat sources in buildings equipped with other heating systems, such as gas heating. In October and November and from February to May, the thermal energy supplied by a collector can decrease indoor heating costs. Solar air collectors can also be used for ventilation, both independently and in conjunction with the main ventilation system. Collectors used for ventilation purposes are equipped with a fan for forced air circulation. The fan can be powered by a photovoltaic module, which makes the ventilation system independent of the power grid. In systems powered by a photovoltaic module, the collector is activated automatically by sunlight. Air flow and temperature can be controlled with the use of additional devices. Solar air collectors supply buildings with fresh and heated air which can be directly used for indoor heating without the involvement of other media. Air flow and air temperature are easily controlled, and the thermodynamic status of premises connected to a solar air collector can be easily monitored. Solar air collectors are an ideal solution for summer cottages to ensure that indoor premises are adequately ventilated and heated outside the season to prevent fungal growth and eliminate musty smell [7].

The maximum thermal efficiency of the analyzed solar air collector approximated $50 \%$, which is a satisfactory result. The maximum thermal efficiency of collectors supplied by renowned manufacturers, such as Solar Venti Ltd., exceeds 70\% (model SV30 Air). According to the latest research conducted by TestLab Solar Thermal Systems of the Fraunhofer Institute for Solar Energy Systems in Germany, the thermal efficiency of innovative Solhotair air collectors exceeds $80 \%$. The results of the present study indicate that a simple and inexpensive solar air collector is characterized by satisfactory thermal efficiency in northern Poland. In November and January, the performance of solar air collectors is significantly compromised by cloudy and foggy weather, which can be attributed to a large number of lakes in the Olsztyn area.

\section{References}

1. W. Smolec, Fototermiczna konwersja energii stonecznej (PWN, Warsaw, Poland, 2000)

2. G. R.Timilsina, L. Kurdgelashvili, P. A. Narb, A review of solar energy; Markets, economics and policie, Polisy Research Working Paper 5845 (Soc. Sci. Res. Netw., 2011)

3. M. Maier, GetSolar software. version 10.1.1. (2009)

4. https://pl.wikipedia.org/wiki/Prawo_Plancka

5. https://upload.wikimedia.org/wikipedia/commons/4/4c/Solar_Spectrum.png

6. https://pl.wikipedia.org/wiki/Prawo_Stefana-Boltzmanna

7. http://www.instsani.pl/401/zasoby-energii-slonecznej

8. https://en.wikipedia.org/wiki/Air_mass_(solar_energy)

9. https://www.newport.com/t/introduction-to-solar-radiation

10. J. Fieducik, J. Godlewski, Czasopismo Inżynierii Lądowej, Środowiska i Architektury, 61 (2014)

11. J. Fieducik, J. Godlewski, Czasopismo Techniczne. Budownictwo, 3-B (2014) 
12. J. Fieducik. Czasopismo Inżynierii Lądowej, Środowiska i Architektury, 63 (2016)

13. T. C. Hung, T. J. Huang, D. S. Lee, C. H. Lin, B. S.Pei, Z. Y. Li, Applied Thermal Engineering, 111 (2017)

14. A. Grine, A. Radjouh, S.Harmand, Solar Energy, 105 (2014)

15. S. Xu, H. Dong, Heat transfer characteristics study on solar air collector of heatabsorbing plate with holes (World Automation Congress Proceedings, 6321398, 2012)

16. P. Charvat, O. Pech, J. Hejcik, EPJ Web of Conferences 45, 01127 (2013)

17. D. Chwieduk, Polish J. of Environ. Stud. 19, 3 (2010)

18. T. Zhu, T. Y. Diao, Y. H. Zhao, F. F. Li, Applied Thermal Engineering, 98 (2016) 